\title{
OGÓLNY MODEL RACHUNKU KOSZTÓW KLIENTA
}

\begin{abstract}
Przedsiębiorstwo w relacjach $\mathrm{z}$ klientami można w sposób bardzo uproszczony przedstawić jako miejsce generowania kosztów a klienta jako źródło dostarczania przychodów. Uproszczenie to znajduje uzasadnienie w roli jaką pełni klient w stosunku do przedsiębiorstwa, bowiem to dzięki klientowi przedsiębiorstwo generuje niezbędne zyski do prowadzenia i kontynuowania działalności oraz swojego rozwoju. Rodzi to konieczność nawiązywania i utrzymywania optymalnych, pod względem ekonomicznym relacji $z$ klientami. W dużej mierze związane jest to stricte $\mathrm{z}$ procesem sprzedaży klientom produktów i/lub towarów, które oferuje lub zamierza oferować przedsiębiorstwo. Podstawowym ryzykiem prowadzenia działalności gospodarczej jest ryzyko związane z opłacalną sprzedażą efektów działalności danego przedsiębiorstwa. Ryzyko to związane jest $\mathrm{z}$ jednej strony $\mathrm{z}$ faktem możliwości dokonania sprzedaży. A $\mathrm{z}$ drugiej strony $\mathrm{z}$ możliwością sprzedaży z zyskiem.

Rentowność relacji z klientami jest kluczowa dla prowadzenia i kontynuowania działalności gospodarczej. Przychody uzyskiwane dzięki relacjom z klientami są łatwe do identyfikacji oraz wyceny. System rachunkowości finansowej w pełni spełnia swoja rolę w tym obszarze. Jednak określenie wszystkich kosztów relacji z danym klientem nie jest sprawą prostą. Rachunkowość finansowa nie jest w stanie w pełni zaspokoić tych potrzeb. Z tego powodu przedsiębiorstwa potrzebują dedykowanego rachunku kosztów, który umożliwi zarządzającym tym przedsiębiorstwami na określenie rzeczywistych kosztów relacji z poszczególnymi klientami.

Celem artykułu jest przedstawienie definicji oraz ogólnego modelu rachunku kosztów klienta sprzyjającego nawiązywaniu i utrzymywaniu rentownych relacji z klientami.

Słowa kluczowe: rachunek kosztów, klient, rentowność, rachunkowość.
\end{abstract}

\section{WPROWADZENIE}

Celem biznesu jest stworzyć i utrzymać klienta ${ }^{2}$. Odzwierciedleniem realizacji tego celu jest podjęcie przez przedsiębiorstwa działań, których efektem będą długotrwałe i rentowne relacje z klientami. Rentowność relacji z klientami wyznacza różnica między przychodami uzyskiwanymi dzięki tym relacjom a kosztami pozyskania i obsługi klientów. Ogólny wynik finansowy przedsiębiorstwa jest stosunkowo łatwo ustalić, jednak wynik finansowy relacji z danym klientem już nie. Spowodowane jest to stopniem złożoności oraz identyfikacji kosztów, które wpływają na ten wynik. Przychody przypisane są do danego klienta przez dokumenty sprzedażowe wystawione na jego dane, ale kosztów tak zidentyfikować się już się nie da - wszystkich kosztów. Część tak, na przykład wartość sprzedanych produktów i/lub towarów bez problemów. Jednak wszystkich kosztów obsługi, czy kosztów pozyskania danego klienta nie można już łatwo

${ }^{1}$ Dr Grzegorz Lew, Zakład Finansów, Bankowości i Rachunkowości, Wydział Zarządzania Politechnika Rzeszowska, email: lewgrzes@prz.edu.pl

${ }^{2}$ T. Levit, Marketing myopia, Harvard Business Review, July/August 1960, s. 45-56. 
zidentyfikować, zmierzyć oraz wycenić. W rozwiązywaniu tych problemów sprzyjają metody rachunkowości zarządczej, a w szczególności dedykowane rachunki kosztów.

Celem artykułu jest przedstawienie definicji oraz ogólnego modelu rachunku kosztów klienta sprzyjającego nawiązywaniu i utrzymywaniu rentownych relacji z klientami.

\section{DEFINICJA RACHUNKU KOSZTÓW KLIENTA}

Rachunek kosztów to „ogół czynności zmierzających do ustalenia wysokości nakładów pracy żywej iuprzedmiotowionej, poniesionych $\mathrm{w}$ przedsiębiorstwie w określonym czasie i z określonym przeznaczeniem”3 lub badanie i przetwarzanie, według przyjętego modelu, informacji o kosztach działalności podmiotu, służące użytkownikom do oceny sytuacji finansowej, podejmowania decyzji gospodarczych i kontroli ich realizacji ${ }^{4}$.

Z tych definicji wynika, iż model rachunku kosztów określa cel, przedmiot i podmiot tego rachunku. W rachunku kosztów klienta można uznać, że:

- $\quad$ celem jego prowadzenia jest dostarczenie zarządzającym użytecznych decyzyjnie informacji na temat kosztów związanych $\mathrm{z}$ relacjami $\mathrm{z}$ klientami oraz $\mathrm{w}$ efekcie umożliwienie ustalenia rentowności tych relacji,

- $\quad$ przedmiotem pomiaru są koszty klienta lub segmentu klientów,

- $\quad$ podmiotem, w którym ten pomiar jest dokonywany jest przedsiębiorstwo prowadzące ten rachunek kosztów.

A zatem rachunek kosztów klienta należy definiować jako proces identyfikacji, klasyfikacji, pomiaru, wyceny, gromadzenia, rozliczania (kalkulowania), analizowania oraz prezentacji kosztów wynikających z nawiązywania, utrzymywania i prowadzenia relacji z klientami oraz wykorzystania zasobów na potrzeby obsługi tych relacji w sposób umożliwiający ustalenie skumulowanych kosztów klienta lub segmentu klientów.

Rachunek kosztów klienta jest bazą ustalenia rentowności klientów lub ich segmentów. Aby możliwe było ustalenie rentowności klientów, identyfikację i analizę przychodów osiąganych dzięki tym klientom należy prowadzić $\mathrm{z}$ taką samą szczegółowością dotyczącą klientów lub ich segmentów jak jest stosowana do identyfikacji kosztów. Pozwoli to na ustalenie wyniku finansowego w przekroju klientów, a odpowiednia konstrukcja rachunku wyników ${ }^{5}$ umożliwi prześledzenie wpływu danych obiektów kosztowych na ogólną rentowność poszczególnych klientów.

Rachunek kosztów klienta powinien zatem obejmować swoim zakresem całość działań przedsiębiorstwa, tak aby w kompleksowy sposób wspierać zarządzających w podejmowaniu przez nich decyzji. Rachunek kosztów jest wyodrębnionym przedmiotowo oraz proceduralnie systemem informacyjnym przedsiębiorstwa.

Rachunek kosztów klienta jest jednolitym zbiorem informacji o kosztach klienta opracowanych według określonego modelu dostosowanego do potrzeb konkretnych użytkowników w danym przedsiębiorstwie.

\footnotetext{
${ }^{3}$ J. Matuszewicz, Rachunek kosztów, Finans - Servis, Warszawa 1994, s. 4.

${ }^{4}$ A. Jarugowa, W. Malc, K. Sawicki, Rachunek kosztów, PWE, Warszawa 1990, s. 54.

5 Rachunek wyników - tworzony jest w zindywidualizowany sposób w celach zarządczych przez dane przedsiębiorstwo, odpowiednik rachunku zysków i strat w rachunkowości finansowej. Jednak rachunek zysków i strat jest znormalizowany normami prawnymi i jego głównym celem jest zaspakajanie potrzeb sprawozdawczych.
} 
W celu zwiększenia w istotny sposób walorów zarządczych rachunku kosztów klienta należy go prowadzić w rachunku ex ante i ex post. W zakres tak rozumianego rachunku kosztów klienta wchodzi:

- określenie warunków ponoszenia kosztów w rachunku kosztów klienta ex ante,

- identyfikacja i oszacowanie wartości kosztów klienta a priori, jako poziomu pożądanego,

- pomiar, wycena oraz ewidencja kosztów rzeczywistych klienta,

- analiza przyczyn powstania odchyleń między kosztami w rachunku ex ante i ex post,

- prezentacja i interpretacja wartości rzeczywistych kosztów klienta.

W konsekwencji informacje uzyskane dzięki tak prowadzonemu rachunkowi kosztów klienta dotyczyć będą działań przyszłych, obecnych i przeszłych. Jednolitość w modelu ex ante i ex post zapewni porównywalność kosztów faktycznie poniesionych $\mathrm{z}$ ich aprioryczną bazą porównawczą ${ }^{6}$. Analiza przyczyn powstawania różnic ustalonych w wyniku tych porównań jest podstawą podejmowania działań zarządczych w przyszłości. Analiza ta stanowi istotny element systemu benchmarkingu ${ }^{7}$ wewnętrznego danego przedsiębiorstwa.

\section{ETAPY TWORZENIA KONCEPCJI MODELU RACHUNKU KOSZTÓW}

\section{KLIENTA}

Projektowanie modelu rachunku kosztów klienta stanowi pierwszy i podstawowy element złożonej procedury opracowania i prowadzenia takiego rachunku w praktyce działalności gospodarczej przedsiębiorstw. Proces ten jest w praktyce procesem ciągłym, w którym można wyodrębnić przede wszystkim cztery etapy (rys. 1):

1) projektowanie - polega na opracowaniu modelu funkcjonowania rachunku kosztów klienta w danym przedsiębiorstwie,

2) wdrażanie - polega na wprowadzeniu do systemu zarzadzania danym przedsiębiorstwem rachunku kosztów klienta,

3) prowadzenie - polega na podejmowaniu w przedsiębiorstwie wielu czynności ukierunkowanych na sprawne funkcjonowanie rachunku kosztów klienta,

4) doskonalenie - ciągłe dostosowywanie rachunku kosztów klienta do zmieniających się potrzeb i warunków funkcjonowania przedsiębiorstwa.

\footnotetext{
${ }^{6}$ Rachunek kosztów. Elementy rachunkowości zarządczej, red. D. Sołtys, Wydawnictwo Akademii Ekonomicznej we Wrocławiu, Wrocław 1999, s. 22.

${ }^{7}$ szerzej: R. Kowalak, Benchmarking jako metoda zarzadzania wspomagajaca controlling przedsiębiorstwa, Wydawnictwo Uniwersytetu Ekonomicznego we Wrocławiu, Wrocław 2009.
} 


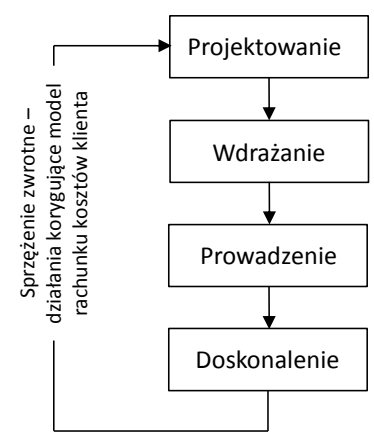

Rys. 1. Opracowanie i funkcjonowanie rachunku kosztów klienta Źródło: Opracowanie własne.

Etap projektowania ma na celu opracowanie modelu rachunku kosztów klienta dostosowanego do potrzeb i specyfiki działania danego przedsiębiorstwa. Działania podejmowane w tym etapie muszą zostać poprzedzone analizą oczekiwań jakie mają zarządzający danym przedsiębiorstwem wobec dedykowanego rachunku kosztów klienta. Dotyczy to przede wszystkim zdiagnozowania obecnego stanu systemu zarzadzania przedsiębiorstwem oraz określania $\mathrm{w}$ jaki sposób ten system ma działać w przyszłości. Analiza ta ma spowodować wybór odpowiedniego modelu rachunku kosztów klienta, który dzięki swojej konstrukcji będzie gwarantował właściwe informacje zarządcze. Działania podejmowane na etapie projektowania można podzielić na trzy fazy:

- fazę projektowania mierników kosztów (identyfikacja, pomiar, wycena),

- fazę projektowania (dostosowania i/lub integrowania) metody rachunku kosztów klienta,

- projektowanie sprawozdawczości i raportowania w rachunku kosztów klienta.

Fazy te wymagają rozstrzygnięcia wielu kwestii szczegółowych. Projektowanie stanowi pierwszy i najbardziej twórczy etap opracowania i prowadzenia rachunku kosztów klienta.

Wdrożenie rachunku kosztów klienta ma charakter techniczny i dotyczy głównie wprowadzenia opracowanego modelu do funkcjonującego systemu zarzadzania przedsiębiorstwem. Opcjonalnie może to się także wiązać $\mathrm{z}$ wdrożeniem dedykowanego kosztowego systemu informatycznego i/lub klasy CRM (customerrelationship management), wspomagającego prowadzenie tego rachunku.

Prowadzenie rachunku kosztów klienta wiąże się z ciągłym jego utrzymywaniem oraz powodowaniem sprawnego działania, w taki sposób, aby spełniał swoje funkcje, czyli na czas dostarczał menedżerom odpowiednich informacji niezbędnych do zarzadzania relacjami z klientami. Oznacza to konieczność okresowego dokonywania weryfikacji tego, czy rachunek ten w właściwy sposób wspomaga proces zarzadzania relacjami z klientami oraz czy nie wymaga modyfikacji. W praktyce działalności gospodarczej przedsiębiorstw warunki działania ulegają ciągłym zmianom, zarówno $\mathrm{w}$ odniesieniu do zewnętrznych, jak i wewnętrznych czynników.

Ciągła optymalizacja działalności przedsiębiorstw i dążenie do budowania i utrzymywania przewagi konkurencyjnej na rynku wymaga doskonalenia również rachunku kosztów klienta i w konsekwencji jego dostosowywanie do zmian zachodzących 
w przedsiębiorstwie i jego otoczeniu biznesowym. Na potrzeby okresowej oceny funkcjonowania rachunku kosztów klienta przeprowadzać można rewizję menedżerską ${ }^{8}$, która zawiera badanie funkcjonowania przedsiębiorstwa i systemu sterowania menedżerskiego. Proces doskonalenia rachunku kosztów klienta można także zaimplementować do jego wnętrza np. poprzez jego integrację $\mathrm{z}$ rachunkiem kaizencosting, czyli rachunkiem ciągłego doskonalenia.

Warunki wyjściowe, a jednocześnie występujące zasadnicze cechy charakterystyczne przedsiębiorstw w zakresie zarządzania relacjami z klientami, które stanowią motywatory opracowania i wdrożenia modelu rachunku kosztów klienta, można określić w następujący sposób:

- Rosnąca konkurencja na globalizujących się rynkach, która wymusza coraz większą koncentrację działań przedsiębiorstw na rzecz klientów.

- Koncentracja działań związanych z pozyskiwaniem informacji dotyczących relacji z klientami poza systemem rachunkowości.

- Brak dokładnych informacji związanych z rzeczywistą rentownością relacji z klientami.

- Wykorzystywanie danych historycznych dotyczących relacji z klientami.

- Duże rozproszenie informacji dotyczących relacji z klientami.

- Brak efektywności niektórych działań w relacjach z klientami.

- Rozproszenie zasobów rzeczowych, kadrowych i finansowych niezbędnych do sprawnego działania rachunku kosztów klienta.

- Potrzeba zmian w obszarze zarządzania relacjami z klientami - wzrost świadomości zarządzających przedsiębiorstwami, którzy w optymalizacji relacji z klientami dostrzegają główne źródło rozwoju swoich przedsiębiorstw.

- Silne oddziaływanie otoczenia biznesowego, szczególnie na styku przedsiębiorstwo- klienci.

- Relatywnie łatwe możliwości pozyskiwania wieloprzekrojowych danych o relacjach z klientami, dzięki zastosowaniu systemów informatycznych.

- Likwidacja barier przestrzennych dla klientów (w przypadku wielu towarów, jednak nie wszystkich) w dotarciu do dostawców prowadzących działalność w innych częściach świata, dzięki kanałowi dystrybucji jakim jest globalna sieć informatyczna internet.

Rosnąca konkurencja zachęca, a wręcz zmusza zarządzających przedsiębiorstwami do poszukiwania skuteczniejszych metod budowania przewagi konkurencyjnej na rynku. Klient jest najważniejszym, a zarazem podstawowym „dostarczycielem” przychodów dla przedsiębiorstw, co determinuje jego znaczącą pozycję w strategiach ich działania. Globalizacja gospodarki światowej, łatwość pozyskania towarów z różnych części świata powodują wzrost znaczenia trwałych, rentownych relacji z klientami.

Koncentracja działań związanych z pozyskaniem informacji dotyczących relacji z klientami poza systemem rachunkowości jest relatywnie powszechnym zjawiskiem wynikającym z niedoceniania możliwości rachunkowości, zarówno finansowej, jak i zarządczej, jako źródła informacji w tym zakresie. Jeżeli przedsiębiorstwo jest zainteresowane zarządzaniem relacjami z klientami to niezbędne dane pozyskiwane są

\footnotetext{
${ }^{8}$ A. A. Jaruga, Rola rachunkowości zarzadczej, [w:] Jaruga A. A., Nowak W.A., Szychta A., Rachunkowość zarzadcza. Koncepcje i zastosowania. WSPiZ, Łódź 2001, s. 25.
} 
raczej w formie ustnej od przedstawicieli handlowych, innych sprzedawców, w działach marketingu, z systemów podatkowych (kasy fiskalne) lub spoza przedsiębiorstwa. System rachunkowości jest również wykorzystywany, ale najczęściej ogranicza się to do zarzadzania należnościami, a nie kompleksowo całością relacji z klientami.

Brak dokładnych informacji związanych z rzeczywistą rentownością relacji $\mathrm{z}$ klientami wynika $\mathrm{z}$ luki informacyjnej w tym zakresie. Istniejące systemy, najczęściej informatyczne klasy CRM (customerrelationship management), wykorzystują w swoich analizach ograniczoną ilość danych, tych które najłatwiej pozyskać. Zaliczyć do nich można przychody ze sprzedaży, koszt sprzedanych towarów, częstotliwość zakupów. Jednak te dane nie są wystarczające do określenia rzeczywistej rentowności relacji z klientami w ujęciu kompleksowym.

Wykorzystywanie danych historycznych dotyczących relacji z klientami wynika z powszechnego stosowania rachunkowości finansowej, która ewidencjonuje operacje gospodarcze, które już wystąpiły. Rachunkowość zarządcza, która jest ukierunkowana także na okresy przyszłe $\mathrm{z}$ racji swej dobrowolności jest stosowana rzadziej i w mniejszym zakresie. Na ten stan rzeczy ma wpływ świadomość kadry zarządzającej, umiejętność pracowników oraz możliwości finansowe przedsiębiorstwa.

Duże rozproszenie informacji dotyczących relacji z klientami najczęściej związane jest $\mathrm{z}$ brakiem systemu zarzadzania ukierunkowanego na te relacje. Rachunkowość finansowa ograniczona jest polityką (zasadami) rachunkowości i realizuje przede wszystkim cele sprawozdawcze, czy podatkowe, a nie zarządcze. $\mathrm{Z}$ tego powodu w rachunkowości finansowej zawarte są niektóre informacje dotyczące relacji z klientami, ale pozyskanie ich wymaga zastosowania dodatkowych procedur. Zakres tych informacji jest również niewystarczający.

Brak efektywności niektórych działań w relacjach z klientami - klient jest tym podmiotem, z punktu widzenia pozyskiwania przychodów, który jest najważniejszy. Z tego powodu wszelkie działania podejmowane przez przedsiębiorstwo, poza obligatoryjnymi, wynikającymi z przepisów prawa, powinny być ukierunkowane na optymalizację relacji $\mathrm{z}$ klientami. Jednak w przedsiębiorstwach realizujących inną strategię niż strategia klienta część działań nie tworzy wartości dla klienta, a więc nie sprzyja zwiększaniu rentowności relacji z klientami.

Rozproszenie zasobów rzeczowych, kadrowych i finansowych niezbędnych do sprawnego działania relacji $\mathrm{z}$ klientami jest zjawiskiem raczej normalnym w praktyce przedsiębiorstw, które nie realizują strategii klienta. Realizacja innych strategii z reguły nie sprzyja skuteczności kompleksowych działań $\mathrm{w}$ ramach relacji $\mathrm{z}$ klientami. Koncentracja tych zasobów na relacjach z klientami może nastąpić w wdrożenia strategii klienta i wykorzystywania rachunku kosztów klienta.

Potrzeba zmian w obszarze zarządzania relacjami z klientami w przedsiębiorstwach to wynik nieustających zmian dokonujących się na rynku. Powoli rosnąca konkurencja na rynku gospodarczym, upowszechnianie się nowych kanałów dystrybucji (kanały elektroniczne), malejące marże zmuszają przedsiębiorstwa do zwracania coraz większej uwagi klientom i ich preferencjom zakupowym. Dynamiczne zmiany na coraz bardziej globalnym rynku sprawiają, że menedżerowie nie są już w stanie ignorować optymalizacji relacji z klientami w swoich decyzjach. Migracja klientów, dzięki nowoczesnym kanałom dystrybucji staje się coraz powszechniejsza.

$\mathrm{Na}$ relatywnie łatwe możliwości pozyskiwania danych duży wpływ ma ciągły dynamiczny rozwój technologii informatycznych. Dedykowane programy wspomagające 
gromadzenie, przetwarzanie i prezentację różnego rodzaju danych finansowych i nie finansowych pozwalają na dostosowanie rodzaju i zakresu rachunku kosztów do konkretnych potrzeb danego przedsiębiorstwa handlowego. Systemy informatyczne rachunkowości finansowej oraz klasy CRM umożliwiają zasilanie w dane, dotyczące klientów, praktycznie każdego rachunku kosztów klienta.

Likwidacja barier przestrzennych dla klientów zmusza przedsiębiorstwa do konkurowania na rynkach globalnych, które są zróżnicowane pod względem kosztochłonności prowadzenia działalności gospodarczej. Oznacza to konieczność konkurowana $\mathrm{z}$ przedsiębiorstwami funkcjonującymi w krajach, gdzie koszty prowadzenia działalności gospodarczej, szczególnie te osobowe, są znacznie niższe niż w krajach europejskich, w tym także w Polsce. Uzasadnia to poszukiwanie przez przedsiębiorstwa narzędzi wspomagających ich $\mathrm{w}$ optymalizacji relacji z klientami, ze szczególnym uwzględnieniem zakresu kosztowego tej działalności.

\section{MODEL RACHUNKU KOSZTÓW KLIENTA}

Badania dedukcyjne, które w swojej istocie mają charakter teoretyczny posługują się $\mathrm{m}$. in. modelowaniem. Modelowanie i modele stanowią podstawowe narzędzie poznania naukowego9. Modelowanie to sposób abstrahowania, prowadzący do odwzorowania w abstrakcie istotnych cech badanej rzeczywistości ${ }^{10}$. Produktem modelowania jest model, który stanowi przybliżenie określonego wycinka sfery realnej, służy do jego wyjaśnienia i zrozumienia, bliższego poznania oraz interpretowania. Model może być rozumiany również jako obiekt manifestujący podobieństwo do czegoś i służący, poprzez zastosowanie uproszczenia, ukazaniu istotnych cech jakiegoś zjawiska ${ }^{11}$. W nauce modeli używa się do gromadzenia i przekazywania posiadanej wiedzy na temat różnych aspektów rzeczywistości. Wykorzystuje się je do odsłaniania rzeczywistości oraz jako instrumenty do wyjaśniania przyszłości i teraźniejszości, a także do przewidywania przeszłości i wpływania na nią ${ }^{12}$. W nauce model reprezentuje więc jedno twierdzenie lub zbiór twierdzeń na temat rzeczywistości. Twierdzenia te mogą dotyczyć faktów, mieć charakter praw lub być koncepcjami teoretycznymi ${ }^{13}$. M. Smith ${ }^{14}$ wymienia wnioskowanie na podstawie budowania modeli jako jedną $\mathrm{z}$ podstawowych metod badawczych $\mathrm{w}$ rachunkowości zarządczej.

Model rachunku kosztów klienta jest zatem uproszczeniem rzeczywistości, konstruowanym po to, aby zrozumieć ten rachunek i móc go zaprojektować w praktyce. Wdrożenie takiego modelu w konkretnym przedsiębiorstwie implikuje dodatkowo potrzebę uwzględnienia oczekiwań informacyjnych zarządzających nim menedżerów, stanu jego otoczenia i wielu innych czynników sytuacyjnych. W związku z tym przedstawiony model rachunku kosztów klienta ma charakter deskryptywny.

\footnotetext{
${ }^{9}$ S. Flejterski, Metodologia finansów, Wydawnictwo Naukowe PWN, Warszawa 2007, s. 157.

${ }^{10}$ Z. Gomółka, Cybernetyka w zarządzaniu. Modelowanie cybernetyczne. Sterowanie systemami, Agencja Wydawnicza Placet, Warszawa 2000, s. 24

${ }^{11}$ W.A. Nowak, O konceptualnej podstawie sprawozdawczości finansowej. Perspektywa angloamerykańska, Wydawnictwo Uniwersytetu Łódzkiego, Łódź 2007, s. 97.

12 B. Nita, Rola rachunkowości zarządczej we wspomaganiu zarzadzania dokonaniami przedsiębiorstwa, Wydawnictwo Uniwersytetu Ekonomicznego we Wrocławiu, Wrocław 2009, s. 249.

${ }^{13}$ R.L. Ackoff, Decyzje optymalne w badaniach stosowanych, Wydawnictwo Naukowe PWN, Warszawa 1969, s. 142 .

${ }^{14}$ M. Smith, Research Methods in Accouting, $3^{\text {th }}$ edition, Sage Publications, London 2014, s. 62.
} 
Każde przedsiębiorstwo jest inne. Na wielorakość przedsiębiorstw wpływa wiele zmiennych. Wśród najważniejszych wymienić można m.in. rozmiar działalności gospodarczej, potencjał rozwojowy, możliwości kapitałowe. Zmienne te w istotny sposób wpływają na możliwości wdrożenia i uzasadnionego ekonomicznie stosowania danego rachunku kosztów klienta. Z tego powodu ogólny model rachunku kosztów klienta powinien być na tyle elastyczny, aby można go było dostosować i wykorzystywać w każdym przedsiębiorstwie, niezależnie od zmiennych różnicujących to przedsiębiorstwo na rynku.

Podstawą opracowania nowego modelu (modeli) rachunku kosztów klienta jest metamodel określający ogólny układ, w którym poprzez odpowiedni pomiar następuje odwzorowanie sytuacji ekonomicznej przedsiębiorstwa. Metamodel powinien określać ramy tworzenia ogólnych modeli rachunku kosztów klienta, które mają zapewnić całościowy, spójny i uniwersalny układ prezentacji informacji tworzących wiarygodny obraz stanu relacji z klientami od strony kosztowej, sporządzony w taki sposób, aby spełniać oczekiwaniach kadry zarządzającej w danym przedsiębiorstwie. Modele te mogą zawierać zasady, zgodnie z którymi model ten może zostać dostosowany do specyfiki konkretnego przedsiębiorstwa. Opracowywane $i$ analizowane na gruncie teorii zarządzania i rachunkowości ogólne modele rachunku kosztów klienta są podstawą indywidualizowania rozwiązań stosowanych w praktyce działalności gospodarczej przedsiębiorstw.

Ogólny model rachunku kosztów klienta w uniwersalnej postaci ${ }^{15}$, który może być uszczegółowiany $\mathrm{w}$ celu dopasowania go do specyficznych potrzeb poszczególnych przedsiębiorstw oraz jego miejsce w rachunku wyników relacji z klientami przedstawia rys. 2.

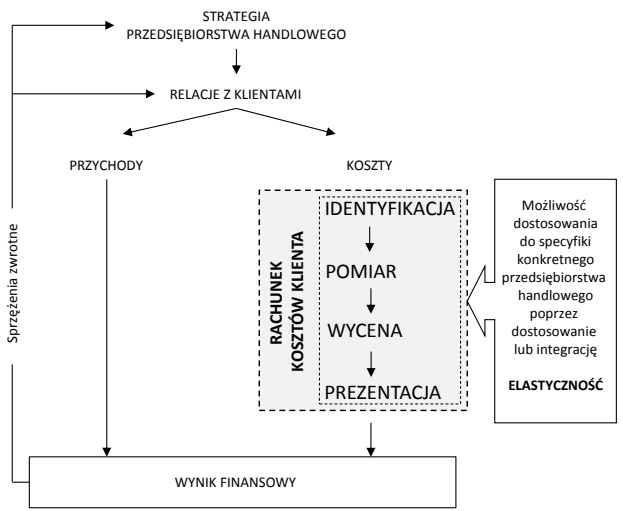

Rys. 2. Ogólny model rachunku kosztów klienta i jego miejsce w rachunku wyników klienta Źródło: Opracowanie własne.

W ogólnym ujęciu rachunek kosztów klienta obejmuje cztery zasadnicze, powiązane ze sobą elementy:

\footnotetext{
15 Szerzej: G. Lew, Rachunek kosztów klienta $w$ zarzadzaniu przedsiębiorstwem handlowym, Oficyna Wydawnicza Politechniki Rzeszowskiej, Rzeszów 2015.
} 
1. Identyfikacja - obiektów kosztowych i działań do nich przynależnych powodujących powstawanie kosztów w relacjach z klientami.

2. Pomiar - metoda wykorzystana do ustalenia wartości poszczególnych kosztów relacji z klientami.

3. Wycena - ustalenie wartości poszczególnych kosztów relacji z klientami.

4. Prezentacja - komunikowanie, w pożądanej przez zarządzających treści i formie, informacji kosztowych dotyczących relacji z klientami.

Te cztery elementy są punktem wyjścia do budowy dedykowanych rachunków kosztów klienta dla poszczególnych przedsiębiorstw. Rachunek kosztów klienta w swojej konstrukcji powinien uwzględniać wielkość przedsiębiorstwa, zasoby intelektualne, otoczenie biznesowe, zasoby kapitałowe oraz potrzeby zarządcze poszczególnych, zainteresowanych tym rachunkiem przedsiębiorstw.

\section{ZAKOŃCZENIE}

Rachunek kosztów klienta jest niezbędnym narzędziem w celu ustalenia rzeczywistej rentowności poszczególnych klientów. Pomiar rentowności poszczególnych klientów pozwalazidentyfikować i zhierarchizować klientów rentownych i nierentownych. Jest to szczególnie ważne w przypadku klientów nierentownych ponieważ utrzymywanie relacji z nimi odbywa się kosztem klientów rentownych, powodując zmniejszenie potencjalnych zysków, które przedsiębiorstwa mogłyby osiągnąć.

Dedykowane rachunki kosztów zintegrowane $\mathrm{z}$ innymi metodami rachunkowości zarządczej stanowią najbliższą przyszłość rozwoju rachunkowości zarządczej. Rachunek kosztów dostosowany do wewnętrznych potrzeb i strategii przedsiębiorstwa jest wystarczającym narzędziem optymalizacji kosztów prowadzenia działalności, szczególnie taki rachunek kosztów, który optymalizuje koszty relacji z głównym, praktycznie jedynym, „dostarczycielem” przychodów jakim jest klient.

\section{LITERATURA}

[1] Ackoff R.L., Decyzje optymalne w badaniach stosowanych, Wydawnictwo Naukowe PWN, Warszawa 1969.

[2] Flejterski S., Metodologia finansów, Wydawnictwo Naukowe PWN, Warszawa 2007.

[3] Gomółka Z., Cybernetyka w zarządzaniu. Modelowanie cybernetyczne. Sterowanie systemami, Agencja Wydawnicza Placet, Warszawa 2000.

[4] Jaruga A. A., Rola rachunkowości zarzadczej, [w:] Jaruga A. A., Nowak W.A., Szychta A., Rachunkowość zarządcza. Koncepcje $i$ zastosowania. WSPiZ, Łódź 2001.

[5] Jarugowa A., Malc W., Sawicki K., Rachunek kosztów, PWE, Warszawa 1990.

[6] Kowalak R., Benchmarking jako metoda zarzadzania wspomagająca controlling przedsiębiorstwa, Wydawnictwo Uniwersytetu Ekonomicznego we Wrocławiu, Wrocław 2009.

[7] Lew G., Rachunek kosztów klienta $w$ zarzadzaniu przedsiębiorstwem handlowym, Oficyna Wydawnicza Politechniki Rzeszowskiej, Rzeszów 2015.

[8] Levit T., Marketing myopia, Harvard Business Review, July/August 1960. 
[9] Matuszewicz J., Rachunek kosztów, Finans - Servis, Warszawa 1994.

[10] Nita B., Rola rachunkowości zarzadczej we wspomaganiu zarządzania dokonaniami przedsiębiorstwa, Wydawnictwo Uniwersytetu Ekonomicznego we Wrocławiu, Wrocław 2009.

[11] Nowak W.A., O konceptualnej podstawie sprawozdawczości finansowej. Perspektywa angloamerykańska, Wydawnictwo Uniwersytetu Łódzkiego, Łódź 2007.

[12] Rachunek kosztów. Elementy rachunkowości zarządczej, red. D. Sołtys, Wydawnictwo Akademii Ekonomicznej we Wrocławiu, Wrocław 1999.

[13] Smith M., Research Methods in Accouting, $3^{\text {th }}$ edition, Sage Publications, London 2014.

\section{GENERAL MODEL OF CUSTOMER COSTS ACCOUNTING}

The company in its dealings with customers can be presented in a very simplistic way as a place of generating costs, and the customer as a source of revenue. This simplification is justified by the role which the customer plays in relation to the company, because it is thanks to the client that company generates profits necessary to keep and continue its business and its development. This raises the need to establish and maintain optimal, in the economic terms, relations with customers. To a large extent this is strictly related to the process of selling products and/or goods, which company offers or intends to offer to customers. The main risk of doing business is the risk associated with profitable sales of effects of business of the given enterprise. The risk is related on one hand to the fact of possibility of making a sale. On the other hand, it is related with the possibility of profitable sales.

The profitability of customer relationships is crucial for conducting and continuing business. Revenues obtained through relationships with customers are easy to identify and evaluate. Financial accounting system fully complies with its role in this area. However, determination of all the costs of relations with a given customer is not a simple matter. Financial accounting is not able to fully meet these needs. For this reason, companies need a dedicated costs accounting, which will enable the management of these companies to determine the actual cost of the relationship with the given customer.

The aim of the article is to present definitions and general model of customer costs accounting favoring establishing and maintaining profitable relationships with customers.

Keywords: costs accounting, customer, profitability, accounting.

DOI:10.7862/rz.2016.hss.23

Przesłano do redakcji: grudzień 2015

Przyjęto do druku: czerwiec 2016 